\title{
Clinicopathological and prognostic significance of PD-L1 expression in colorectal cancer: a meta-analysis
}

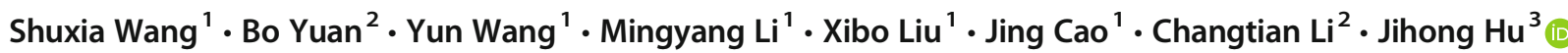

Accepted: 26 August 2020 / Published online: 10 September 2020

(C) The Author(s) 2020

\begin{abstract}
Purpose To systematically evaluate the correlation between PD-L1 expression and clinicopathological features and prognosis of colorectal cancer (CRC).

Methods Seven databases (PubMed, Cochrane Library, EMBASE, Web of Science, CBM, Wanfang, and CNKI) were searched through May 2020. Risk of bias and quality of evidence were assessed by using the Newcastle-Ottawa scale (NOS), and metaanalysis was carried out by using the Review Manager 5.3 software on the studies with the quality evaluation scores $\geq 6$. Metaregression analysis was used to determine the independent role of PD-L1 expression on CRC prognosis after adjusting clinicopathological features and treatment methods.

Results A total of $8823 \mathrm{CRC}$ patients in 32 eligible studies. PD-L1 expression was correlated with lymphatic metastasis (yes/no; $\mathrm{OR}=1.24,95 \% \mathrm{CI}(1.11,1.38))$, diameter of tumor $(\geq 5 \mathrm{~cm} /<5 \mathrm{~cm}$; OR $=1.34,95 \% \mathrm{CI}(1.06,1.70))$, differentiation (highmiddle/low; $\mathrm{OR}=0.68,95 \% \mathrm{CI}(0.53,0.87)$ ), and vascular invasion (yes $/ \mathrm{no} ; \mathrm{OR}=0.80,95 \% \mathrm{CI}(0.69,0.92))$. PD-L1 expression shortened the overall survival (hazard ratio $(\mathrm{HR})=1.93,95 \% \mathrm{CI}(1.66,2.25)$ ), disease-free survival $(\mathrm{HR}=1.76,95 \% \mathrm{CI}(1.50$, $2.07)$ ), and progression-free survival $(\mathrm{HR}=1.93,95 \% \mathrm{CI}(1.55,2.41))$. Meta-regression showed that PD-L1 expression played a significant role on poor CRC OS $(\mathrm{HR}=1.95,95 \% \mathrm{CI}(1.92,3.98))$ and disease-free survival $(\mathrm{HR}=2.14,95 \% \mathrm{CI}(0.73,4.52))$. Conclusion PD-L1 expression independently predicted a poor prognosis of CRC.
\end{abstract}

Keywords Programmed death ligand-1 (PD-L1) · Colorectal cancer (CRC) · Prognosis · Clinicopathological features * Meta-analysis

\section{Introduction}

Colorectal cancer $(\mathrm{CRC})$ is one of the most common malignant tumors of the digestive system all around the world [1]. Its incidence and mortality rate ranked third and

Electronic supplementary material The online version of this article (https://doi.org/10.1007/s00384-020-03734-4) contains supplementary material, which is available to authorized users.

Jihong $\mathrm{Hu}$

hujihonghappy@163.com

1 Public Health School, Gansu University of Chinese Medicine, Lanzhou 730000, China

2 Basic Medical School, Gansu University of Chinese Medicine, Lanzhou 730000, China

3 Center of Research and Experiment, Gansu University of Chinese Medicine, Lanzhou 730000, China second in the world, respectively [2]. In 2018, both new cases and deaths were close to $30 \%$ of the total number of CRC cases in the world [3, 4]. China's cancer statistics indicated that the incidence and mortality of CRC ranked fifth among all malignant tumors in China, bringing about 380,000 new cases and 190,000 deaths annually [5]. Furthermore, most patients have already been in the severe stage when they were seeking the medical examination $[6$, 7]. Thus, it has become a major public health problem in many countries $[8,9]$.

Surgery, chemotherapy, and radiation therapy are the main treatments for cancer; unfortunately, the recurrence rate and metastasis rate (approximately $30 \%$ and $10 \%$ ) in advanced CRC patients still remain high $[10,11]$. In addition, some treatments showed only mild effects in reducing tumor load, such as cytokine therapy, toll-like receptors, and autologous cell therapy [12]. In recent years, immune card control point drugs have provided a new therapy for CRC, especially the programmed death 1 (PD-1)/programmed death ligand-1(PD- 
L1) monoclonal antibody as an immunodetection point inhibitor and an antibody-type tumor immune drug [13, 14]. PDL1, also known as CD274 or B7-H1, is the ligand PD-1 and a sort of immune checkpoint inhibitors and belongs to the CD28 family and is expressed on the surface of activated $\mathrm{T}$ cells to regulate proliferation and activation [15]. The binding of PDL1 on tumor cells to PD-1 on lymphocytes can lead to immune escape of tumor cells and ultimately promote the generation and development of tumors by inhibiting the release of cytokines, restricting lymphocyte function, and inducing lymphocyte apoptosis [16]. It was reported that PD-L1 correlated with the clinicopathological features and affected the prognosis of cancers (such as breast, gastric, and ovarian cancers) [17-19].

The correlation between PD-L1 expression and clinicopathological features of $\mathrm{CRC}$ was inconsistent, and the independent impacts of PD-L1 expression on CRC prognosis were unclear in the previous meta-analyses [20-23]. Additionally, some limitations reduced the reliability because of small sample sizes $[21,23]$ or the high heterogeneity $[21,23]$ or incorrect model selection $[21,23]$. Thus, we aimed to update a meta-analysis of cohort studies to confirm the correlation between PD-L1 expression and clinicopathological features, and perform a meta-regression analysis to determine the independent role of PD-L1 on CRC prognosis after adjusting confounders.

Fig. 1 Flowchart of document retrieval

\section{Materials and method}

\section{Search strategy}

Seven databases (PubMed, Cochrane Library, EMBASE, Web of Science, CBM, Wanfang, and CNKI) were searched through May 2020, and the search strategies were ("PD-L1" OR" B7H1" OR "Programmed Cell Death Ligand 1" OR “CD274” OR "PD-1" OR "Programmed death 1") AND ("Colorectal Cancer” OR “Colorectal Neoplasm” OR "Colorectal Tumor" OR “Colorectal Carcinoma” OR "Colorectal Cancer" OR "Rectal Cancer” OR “Colon Cancer” OR "Rectal Neoplasm” OR “Colon Neoplasm"). Furthermore, we reviewed the reference list of original and review articles to search for more studies. Only studies that were published as full articles and in Chinese and English were considered.

\section{Inclusion and exclusion criteria}

Inclusion criteria for study enrollment were (1) cohort studies; (2) patients had confirmed colorectal cancer; (3) PD-L1 expression detected method: immunohistochemistry (IHC); (4) the literature provides the relationship between PD-L1 expression and clinicopathological features, such as sex, age, lymphatic metastasis, differentiation, TNM stage, and tumor location; (5) studies that provided detailed pathological parameters and survival
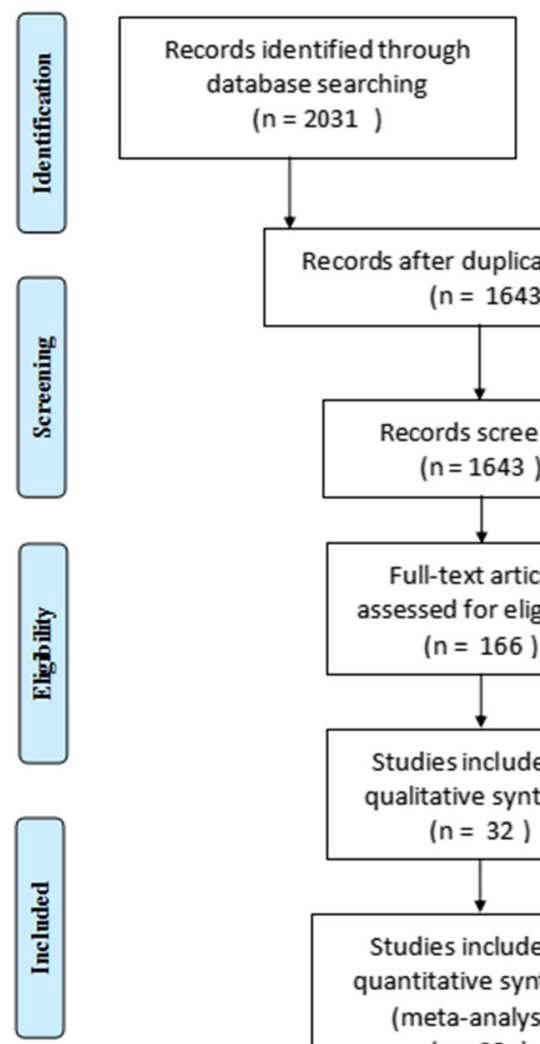

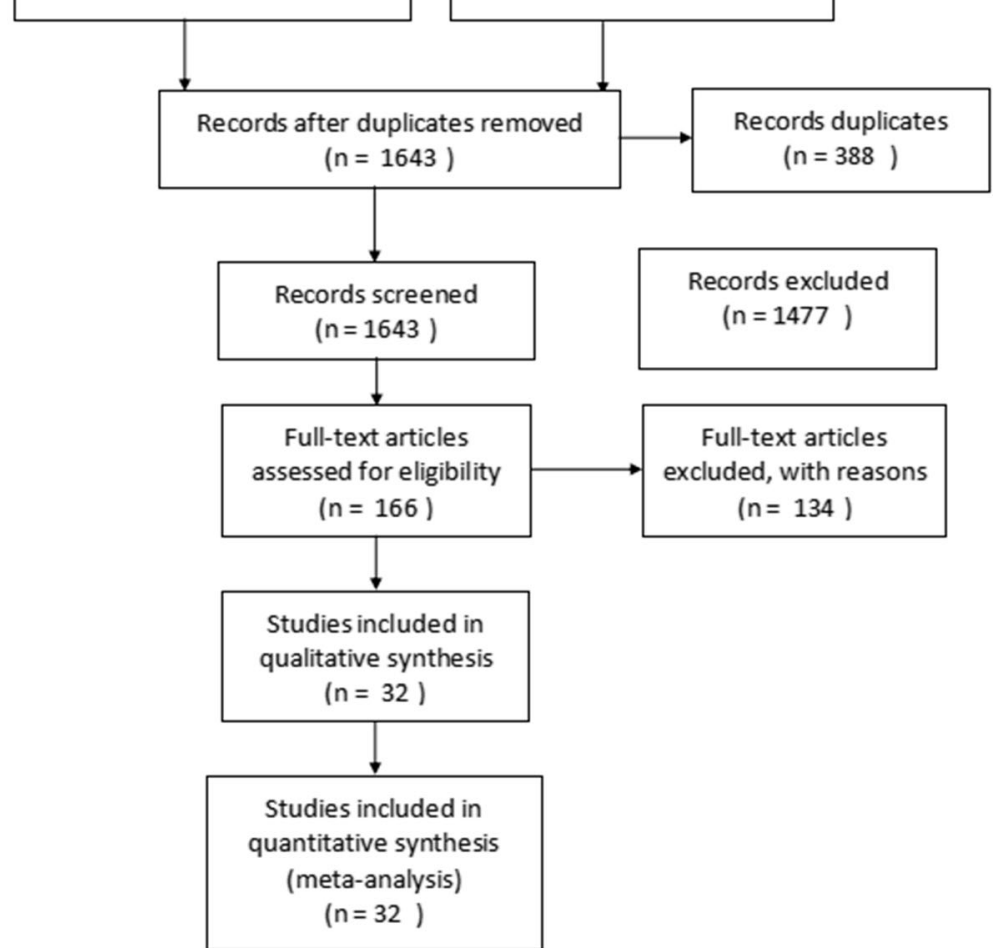

Additional records identified through other sources $(n=0)$ 


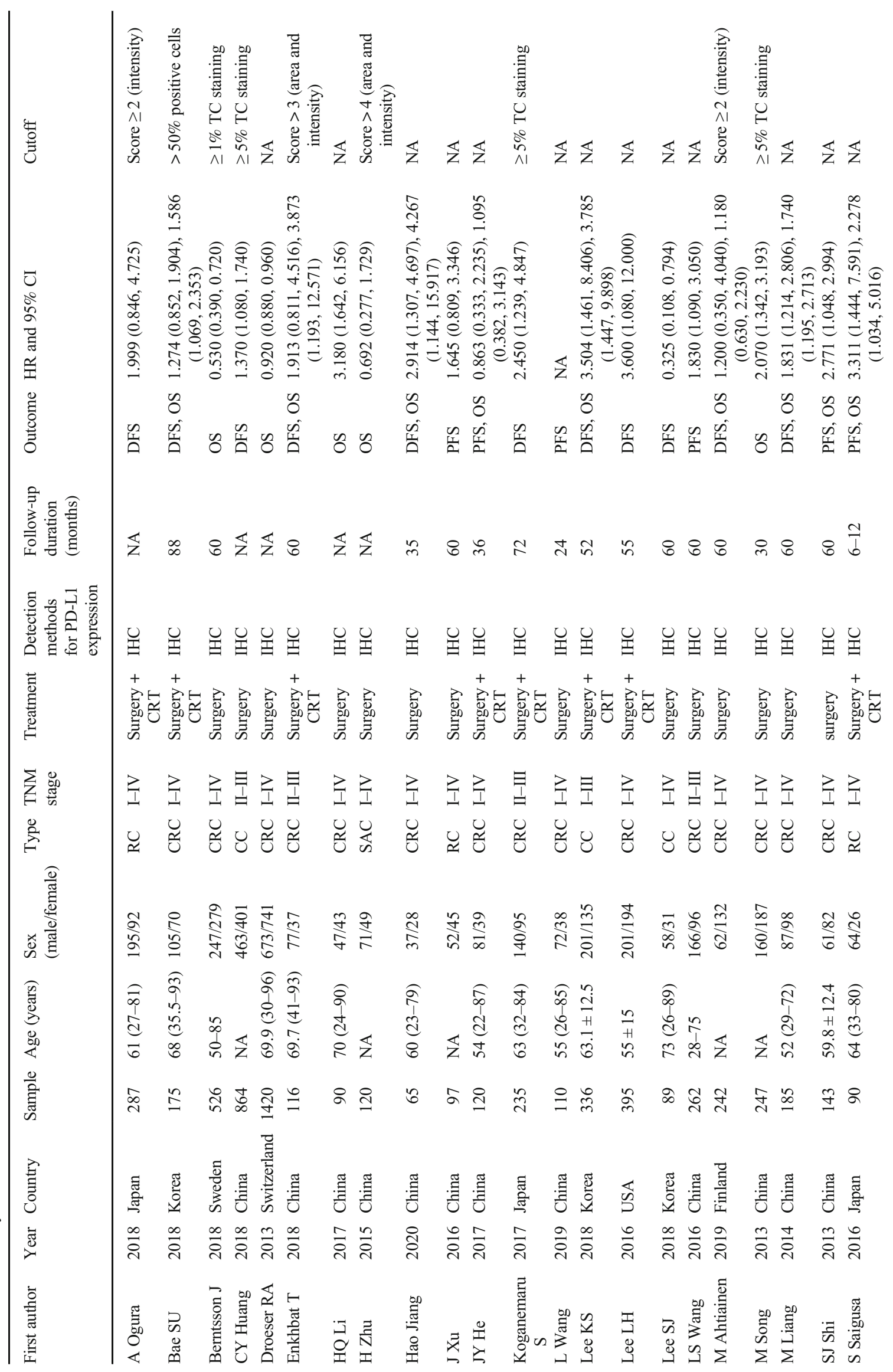




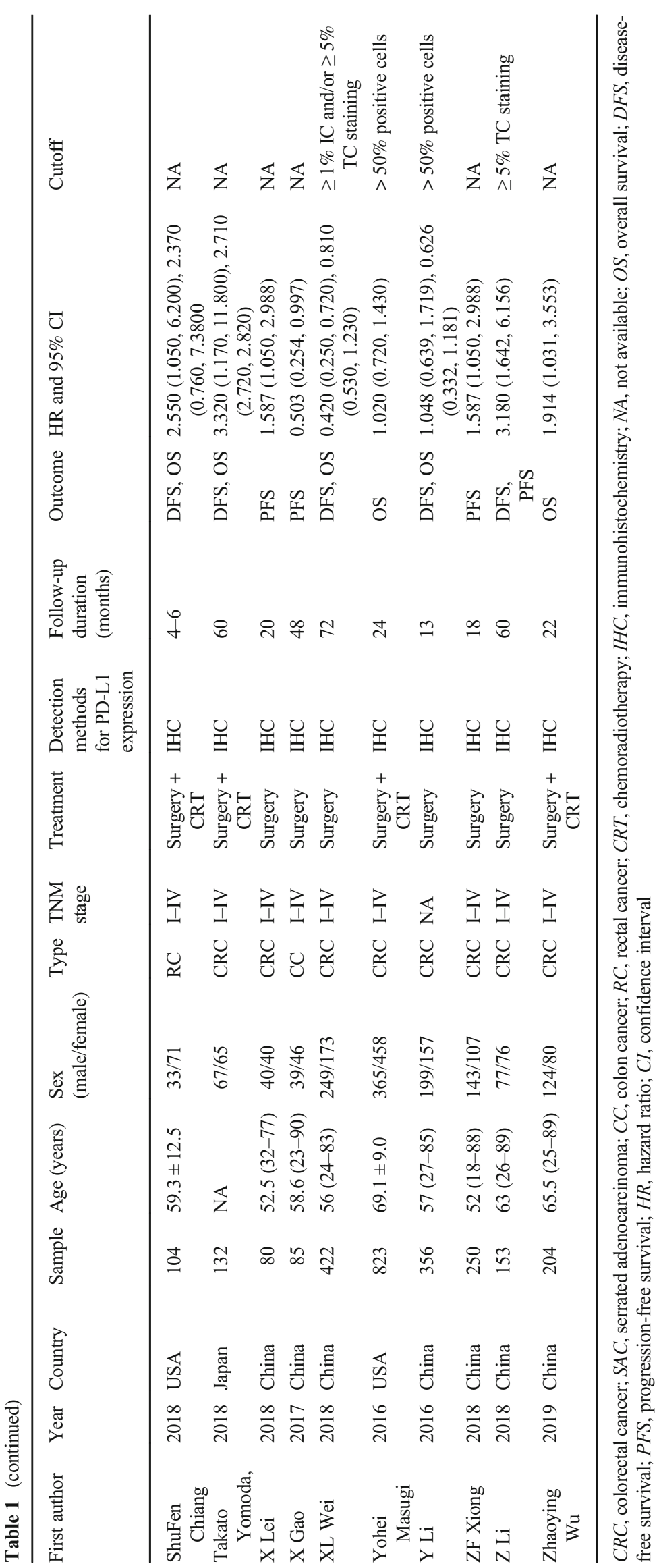


Table 2 Methodological quality evaluation of included studies by using the NOS

\begin{tabular}{|c|c|c|c|c|c|c|c|c|c|}
\hline \multirow[t]{2}{*}{ First author } & \multirow{2}{*}{$\begin{array}{l}\text { Published } \\
\text { year }\end{array}$} & \multicolumn{3}{|c|}{ Sample selection } & \multirow{2}{*}{$\begin{array}{l}\text { Comparability? } \\
\text { Comparability? }\end{array}$} & \multicolumn{3}{|l|}{ Outcome } & \multirow{2}{*}{$\begin{array}{l}\text { NOS } \\
\text { score }\end{array}$} \\
\hline & & $\begin{array}{l}\text { Case } \\
\text { definition } \\
\text { adequate? }\end{array}$ & $\begin{array}{l}\text { Representativeness } \\
\text { of the cases? }\end{array}$ & $\begin{array}{l}\text { Ascertainment } \\
\text { of exposure }\end{array}$ & & $\begin{array}{l}\text { Assessment } \\
\text { of outcome? }\end{array}$ & $\begin{array}{l}\text { Was follow-up } \\
\text { long enough for } \\
\text { outcomes to oc- } \\
\text { cur? }\end{array}$ & $\begin{array}{l}\text { Description } \\
\text { of follow- } \\
\text { up? }\end{array}$ & \\
\hline A Ogura & 2018 & + & + & + & + & + & + & - & 6 \\
\hline Bae SU & 2018 & + & + & + & + & + & + & + & 7 \\
\hline Berntsson J & 2018 & + & + & + & + & + & + & + & 7 \\
\hline CY Huang & 2018 & + & + & + & + & + & + & + & 7 \\
\hline Droeser RA & 2013 & + & + & + & + & + & + & + & 7 \\
\hline Enkhbat T & 2018 & + & + & + & + & + & + & + & 6 \\
\hline HQ Li & 2017 & + & + & + & + & + & - & - & 6 \\
\hline H Zhu & 2015 & + & + & + & + & + & + & - & 6 \\
\hline Hao Jiang & 2020 & + & + & + & + & + & + & + & 7 \\
\hline $\mathrm{J} \mathrm{Xu}$ & 2016 & + & + & + & + & + & + & + & 7 \\
\hline $\mathrm{JY} \mathrm{He}$ & 2017 & + & + & + & + & + & + & + & 7 \\
\hline Koganemaru S & 2017 & + & + & + & + & + & + & + & 7 \\
\hline L Wang & 2019 & + & + & + & + & + & + & + & 7 \\
\hline Lee KS & 2018 & + & + & - & + & + & + & + & 6 \\
\hline Lee LH & 2016 & + & + & + & + & + & + & + & 7 \\
\hline Lee SJ & 2018 & + & + & + & + & + & + & + & 7 \\
\hline LS Wang & 2016 & + & + & + & + & + & + & + & 7 \\
\hline M Ahtiainen & 2019 & + & + & + & + & + & + & + & 7 \\
\hline M Song & 2013 & + & + & + & + & + & + & + & 7 \\
\hline M Liang & 2014 & + & + & + & + & + & + & + & 7 \\
\hline SJ Shi & 2013 & + & + & + & + & + & + & + & 7 \\
\hline S Saigusa & 2016 & + & + & + & + & + & + & + & 7 \\
\hline $\begin{array}{l}\text { ShuFen } \\
\text { Chiang }\end{array}$ & 2018 & + & + & + & + & + & + & + & 7 \\
\hline $\begin{array}{l}\text { Takato } \\
\text { Yomoda }\end{array}$ & 2018 & + & + & + & + & + & + & + & 7 \\
\hline X Lei & 2018 & + & + & + & + & + & + & + & 7 \\
\hline X Gao & 2017 & + & + & + & + & + & + & + & 7 \\
\hline XL Wei & 2018 & + & + & + & + & + & + & + & 7 \\
\hline Yohei Masugi & 2016 & + & + & + & + & + & + & + & 7 \\
\hline Y Li & 2016 & + & + & + & + & + & + & + & 7 \\
\hline ZF Xiong & 2018 & + & + & + & + & + & + & + & 7 \\
\hline $\mathrm{Z} \mathrm{Li}$ & 2018 & + & + & + & + & + & + & + & 7 \\
\hline Zhaoying Wu & 2019 & + & + & + & + & + & + & + & 7 \\
\hline
\end{tabular}

outcomes; and (6) studies that provided hazard ratios and $95 \%$ confidence interval $(\mathrm{CI})$ to calculate survival outcomes. The exclusion criteria were (1) studies that were case reports, reviews, or conference papers; (2) republished literature, reviews, and case series; and (3) full text not available.

\section{Data extraction}

Two researchers (Shuxia Wang and Yun Wang) identified and classified the literature that met the inclusion criteria independently and excluded the study that obviously did not meet the inclusion criteria after reading the full text. For studies with insufficient information, we contacted the primary authors to acquire and verify data when possible. In cases of disagreement, the two researchers can make an attempt to reach a consensus. We extracted these objective data which were analyzed for aims of this study : (1) the basic information of the study including first author, year of publication, country, number of subjects, their demographic features, (2) type of study, (3) treatment method, (4) outcomes including the pathological parameters (sex, age, tumor location, TNM stage, lymphatic metastasis, differentiation, infiltration degree, tumor diameter, distant metastasis, and vascular invasion), and (5) prognostic values including overall survival (OS), diseasefree survival (DFS) and progression-free survival (PFS).

\section{Quality assessment}

Study quality was assessed by using the Newcastle-Ottawa score [24], which consists of three factors: patients selection, comparability of study groups, and assessment of outcomes. 


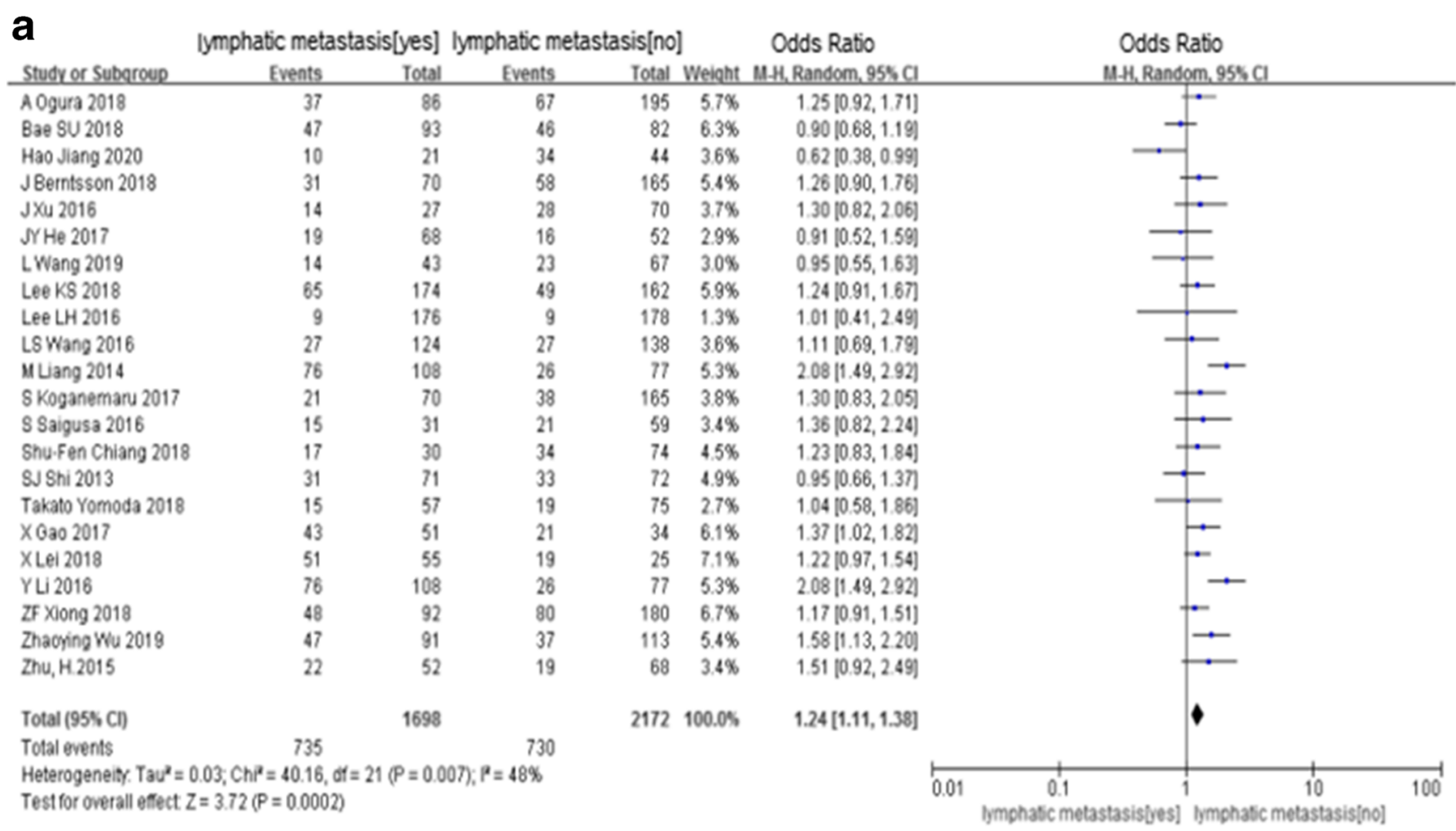

b

$$
>=5 \mathrm{~cm} \quad<5 \mathrm{~cm}
$$

Odds Ratio

Odds Ratio

Study or Subaroup Events Total Events Total Weiaht M-H, Fixed, 95\% Cl

M.H. Fixed, $95 \% \mathrm{Cl}$

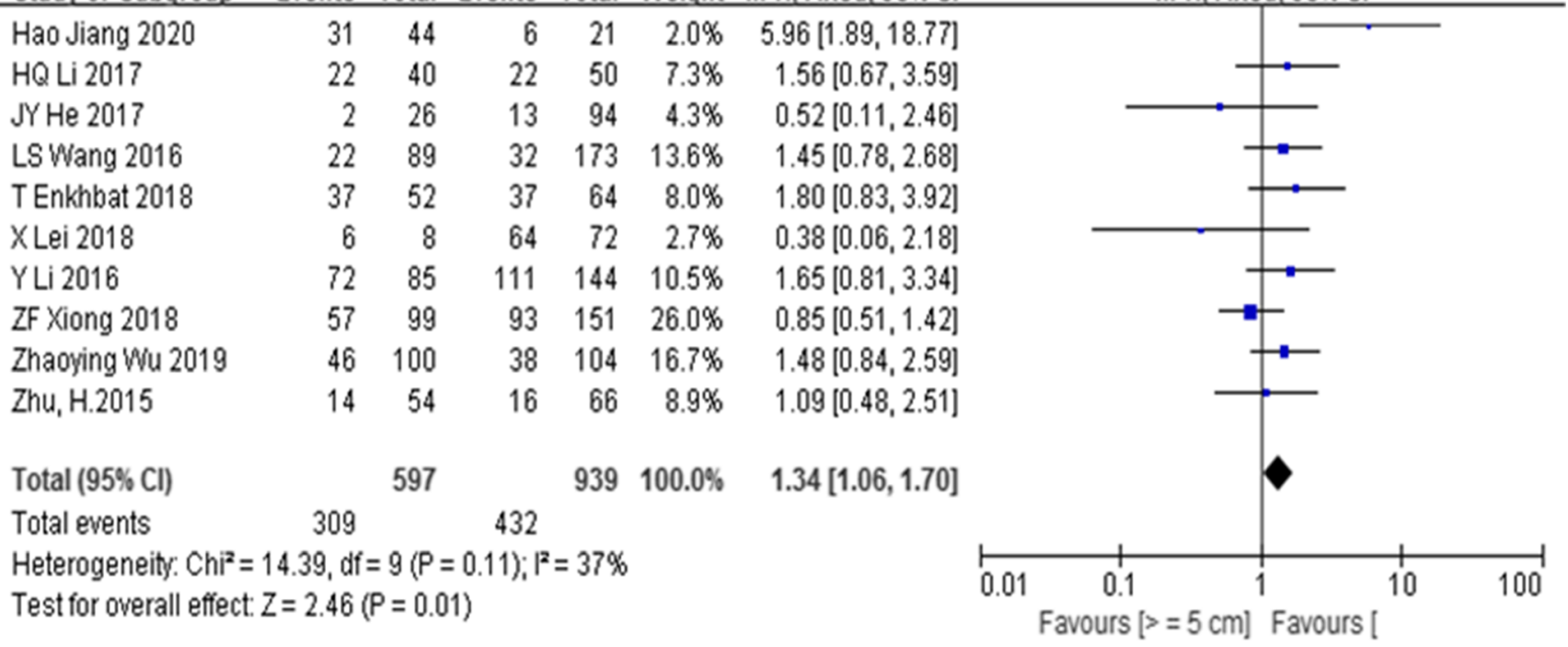

Fig. 2 Meta-analysis between PD-L1 expression and lymphatic metastasis (a) and tumor diameter (b)

A score of 0 to 9 was assigned to each study, and studies achieving a score of 6 or higher were considered high quality.

\section{Statistical analysis}

If the numbers of included studies were less than 3 , the metaanalysis could not be used. All statistical analyses were conducted by using Review Manager 5.3. Odds ratios (OR) and 95\% CI were analyzed for the relationship between PD-L1 expression and basic clinicopathological features including sex (male/female), age $(\geq 60 /<60$ years old), tumor location (right + rectum/left + colon), TNM stage (III-IV/I-II), lymphatic metastasis (yes/no), differentiation (high-middle/low), tumor diameter $(\geq 5 \mathrm{~cm} /<$ $5 \mathrm{~cm}$ ), vascular invasion (yes/no), infiltration degree (3-4/1-2), and distant metastasis (yes/no). Hazard ratio (HR) and its $95 \% \mathrm{CI}$ were presented for PD-L1 on CRC prognosis. Subgroup analysis was used to find the source of heterogeneity according to treatment methods (surgery or surgery combined with chemoradiotherapy (CRT)). Moreover, meta-regression analysis was used to analyze the independent role of PD-L1 on the prognosis of CRC 


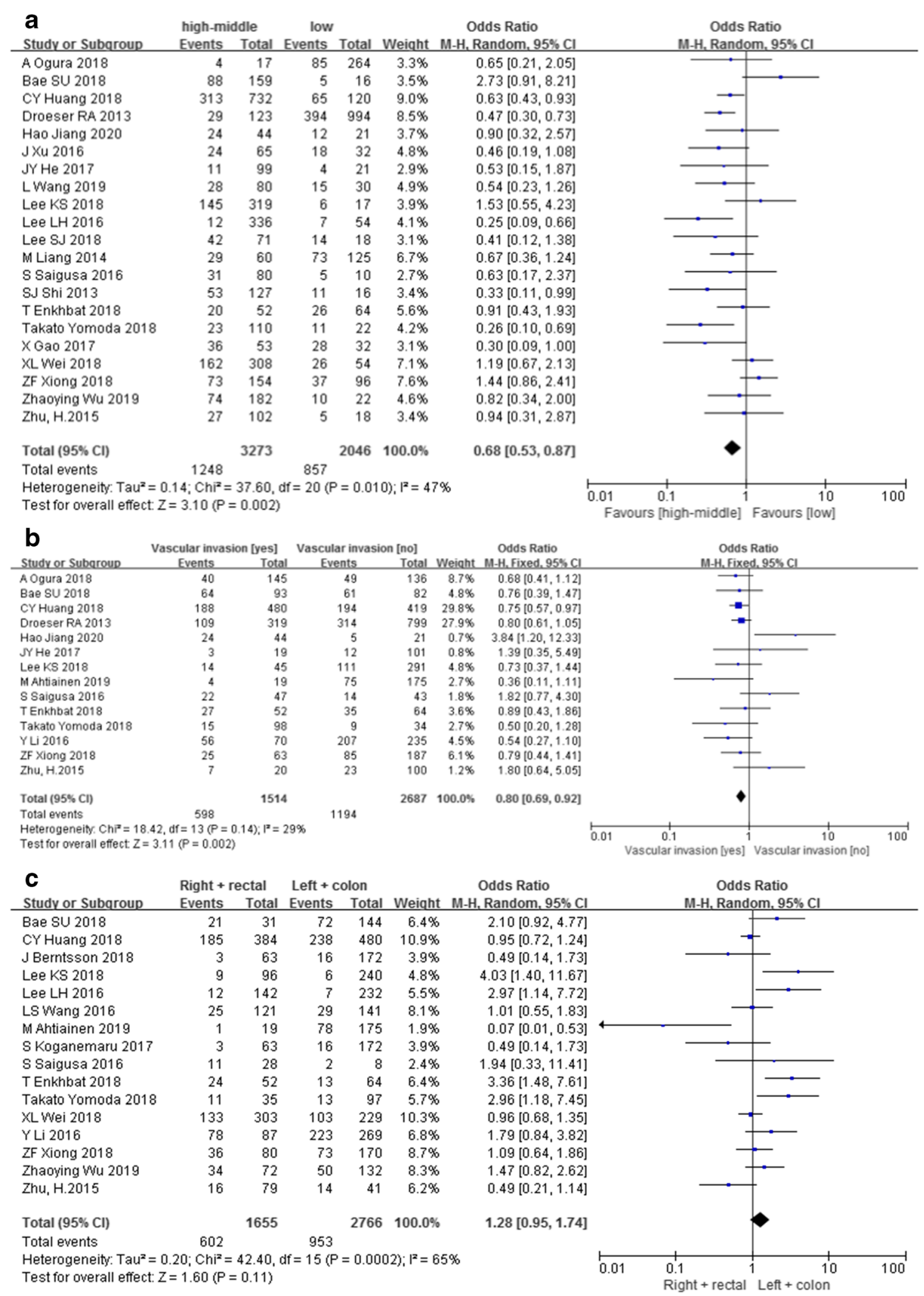

Fig. 3 Meta-analysis between PD-L1 expression and differentiation (a) and vascular invasion (b) and tumor location (c)

after adjusting for above clinicopathological features and treatment methods. If the numbers of included studies were less than
10, the meta-regression could not be used. Depending on the results from the tests of heterogeneity, a fixed effect model or a 


\begin{tabular}{|c|c|c|c|c|c|c|c|c|}
\hline $\begin{array}{l}\text { a } \\
\text { Study or Subaroup loc }\end{array}$ & ard Ratiol & SE & Weight I & $\begin{array}{l}\text { Hazard Ratio } \\
\text { IV, Random, } 95 \% \mathrm{Cl}\end{array}$ & & $\begin{array}{l}\text { Hazard } \\
\text { IV. Randon }\end{array}$ & $\begin{array}{l}\text { Ratio } \\
\mathrm{m}, 95 \% \mathrm{Cl}\end{array}$ & \\
\hline Bae SU 2018 & 0.4612151 & 0.2012672 & $7.2 \%$ & $1.59[1.07,2.35]$ & & & 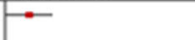 & \\
\hline Droeser RA 2013 & 0.833816 & 0.221968 & $6.6 \%$ & $2.30[1.49,3.56]$ & & & $\rightarrow$ & \\
\hline Hao Jiang 2020 & 1.450911 & 0.6716471 & $1.2 \%$ & $4.27[1.14,15.92]$ & & & & \\
\hline HQ Li 2017 & 1.156881 & 0.3371205 & $3.9 \%$ & $3.18[1.64,6.16]$ & & & $\longrightarrow$ & \\
\hline J Berntsson 2018 & 0.6348783 & 0.1564042 & $9.0 \%$ & $1.89[1.39,2.56]$ & & & $\rightarrow$ & \\
\hline JY He 2017 & 0.0907544 & 0.5376307 & $1.8 \%$ & $1.10[0.38,3.14]$ & & & & \\
\hline Lee KS 2018 & 1.331046 & 0.4905205 & $2.1 \%$ & $3.79[1.45,9.90]$ & & & $\longrightarrow$ & \\
\hline M Antiainen 2019 & 0.1655144 & 0.3224584 & $4.1 \%$ & $1.18[0.63,2.22]$ & & & $\square$ & \\
\hline M Liang 2014 & 0.5538851 & 0.2091604 & $7.0 \%$ & $1.74[1.15,2.62]$ & & & 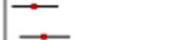 & \\
\hline M Song 2013 & 0.7275486 & 0.2211224 & $6.6 \%$ & $2.07[1.34,3.19]$ & & & $\rightarrow$ & \\
\hline S Koganemaru 2017 & 0.8960881 & 0.3479733 & $3.7 \%$ & $2.45[1,24,4.85]$ & & & & \\
\hline S Saigusa 2016 & 0.8232979 & 0.4028566 & $3.0 \%$ & $2.28[1.03,5.02]$ & & & & \\
\hline Shu-Fen Chiang 2018 & 0.8628899 & 0.5799006 & $1.6 \%$ & $2.37[0.76,7.39]$ & & & & \\
\hline SJ Shi 2013 & 1.019208 & 0.2677874 & $5.3 \%$ & $2.77[1.64,4.68]$ & & & $\longrightarrow$ & \\
\hline $\begin{array}{l}\text { T Enkhbat } 2018 \\
\text { Takato Yomoda } 2018\end{array}$ & $\begin{array}{r}1.354029 \\
0.9969487\end{array}$ & $\begin{array}{r}0.6007435 \\
0.136939\end{array}$ & $\begin{array}{l}1.5 \% \\
9.8 \%\end{array}$ & $\begin{array}{r}3.87[1.19,12.57] \\
2.71[2.07,3.54]\end{array}$ & & & $\rightarrow$ & \\
\hline XL Wei 2018 & 0.210721 & 0.2147685 & $6.8 \%$ & $1.23[0.81,1.88]$ & & & - & \\
\hline YLI 2016 & 0.4684049 & 0.3237199 & $4.1 \%$ & $1.60[0.85,3.01]$ & & & & \\
\hline Yohei Masugi 2016 & 0.198026 & 0.1750455 & $8.2 \%$ & $1.22[0.86,1.72]$ & & & - & \\
\hline Zhaoying Wu 2019 & 0.6491953 & 0.3156283 & $4.3 \%$ & $1.91[1.03,3.55]$ & & & $\longrightarrow$ & \\
\hline Zhu, H.2015 & 0.3681694 & 0.4671635 & $2.3 \%$ & $1.45[0.58,3.61]$ & & & & \\
\hline Total $(95 \% \mathrm{Cl})$ & & & $100.0 \%$ & $1.93[1.66,2.25]$ & & & $\downarrow$ & \\
\hline $\begin{array}{l}\text { Heterogeneity: } \operatorname{Tau}^{z}=0 \text {. } \\
\text { Test for overall effect: } Z\end{array}$ & $\begin{array}{l}\mathrm{i}^{2}=32.88, \mathrm{df}= \\
(\mathrm{P}<0.00001)\end{array}$ & $=20(P=0.03$ & 3); $1^{2}=399$ & & 0.01 & ${ }_{\text {Favors [PD-L1+] }}^{0.1}$ & ${ }^{1} \frac{10}{\text { Favors [PD-L1-] }}$ & $100^{\circ}$ \\
\hline $\begin{array}{l}\text { b } \\
\text { Study or Subqroup }\end{array}$ & azard Ratio] & SE & Weight & $\begin{array}{l}\text { Hazard Ratio } \\
\text { IV, Fixed, } 95 \% \mathrm{Cl}\end{array}$ & & $\begin{array}{l}\text { Hazard Re } \\
\text { IV, Fixed, }\end{array}$ & $\begin{array}{l}\text { Ratio } \\
.95 \% \mathrm{Cl}\end{array}$ & \\
\hline 2.2.1 DFS & & & & & & & & \\
\hline A Ogura 2018 & 0.692647 & 0.4388019 & $2.3 \%$ & $2.00[0.85,4.72]$ & & & & \\
\hline Bae SU 2018 & 0.2421616 & 0.2051341 & $10.4 \%$ & $1.27[0.85,1.90]$ & & & - & \\
\hline CYHuang 2018 & 0.3148108 & 0.2216643 & $8.9 \%$ & $1.37[0.89,2.12]$ & & & - & \\
\hline Hao Jiang 2020 & 1.069527 & 0.4090832 & $2.6 \%$ & $2.91[1.31,6.50]$ & & & $\longrightarrow$ & \\
\hline Lee KS 2018 & 1.253905 & 0.4463838 & $2.2 \%$ & $3.50[1.46,8.40]$ & & & & \\
\hline Lee LH 2016 & 1.280934 & 0.6142718 & $1.2 \%$ & $3.60[1.08,12.00]$ & & & & \\
\hline Lee S.J 2018 & 1.12393 & 0.5089104 & $1.7 \%$ & $3.08[1.13,8.34]$ & & & & \\
\hline M Ahtiainen 2019 & 0.0198026 & 0.6239966 & $1.1 \%$ & $1.02[0.30,3.47]$ & & & & \\
\hline M Liang 2014 & 0.6048623 & 0.2137345 & $9.5 \%$ & $1.83[1.20,2.78]$ & & & $\rightarrow$ & \\
\hline S Koganemaru 2017 & 0.8960881 & 0.3479733 & $3.6 \%$ & $2.45[1.24,4.85]$ & & & & \\
\hline Shu-Fen Chiang 2018 & 0.9360933 & 0.4529998 & $2.1 \%$ & $2.55[1.05,6.20]$ & & & & \\
\hline T Enkhbat 2018 & 0.6486727 & 0.4380392 & $2.3 \%$ & $1.91[0.81,4.51]$ & & & & \\
\hline Takato Yomoda 2018 & 1.199965 & 0.5895563 & $1.3 \%$ & $3.32[1.05,10.54]$ & & & & \\
\hline XL Wei 2018 & 0.8675006 & 0.2698445 & $6.0 \%$ & $2.38[1.40,4.04]$ & & & $\rightarrow$ & \\
\hline YLi 2016 & 0.0468836 & 0.2524473 & $6.8 \%$ & $1.05[0.64,1.72]$ & & & - & \\
\hline Z Li 2018 & 0.5242487 & 0.3301748 & $4.0 \%$ & $1.69[0.88,3.23]$ & & & & \\
\hline Subtotal $(95 \% \mathrm{Cl})$ & & & $65.8 \%$ & $1.76[1.50,2.07]$ & & & $\checkmark$ & \\
\hline $\begin{array}{l}\text { Heterogeneity: } \mathrm{Chi}^{2}=1 \mathrm{~g} \\
\text { Test for overall effect: } Z\end{array}$ & $\begin{array}{l}f=15(P=0.2 \\
(P<0.00001\end{array}$ & 1) & & & & & & \\
\hline $\begin{array}{l}\text { C } \\
2.2 .2 \mathrm{PFS}\end{array}$ & & & & & & & & \\
\hline J Xu 2016 & 0.4977404 & 0.362174 & $3.3 \%$ & $1.65[0.81,3.35]$ & & & & \\
\hline JY He 2017 & 0.1473406 & 0.485677 & $1.8 \%$ & $1.16[0.45,3.00]$ & & & & \\
\hline LS Wang 2016 & 0.604316 & 0.2624908 & $6.3 \%$ & $1.83[1.09,3.06]$ & & & $\because$ & \\
\hline S Saigusa 2016 & 1.19725 & 0.4233536 & $2.4 \%$ & $3.31[1.44,7.59]$ & & & & \\
\hline SJ Shi 2013 & 1.019208 & 0.2677874 & $6.1 \%$ & $2.77[1.64,4.68]$ & & & $\rightarrow$ & \\
\hline X Gao 2017 & 0.6871651 & 0.3488307 & $3.6 \%$ & $1.99[1.00,3.94]$ & & & & \\
\hline X Lei 2018 & 0.8064759 & 0.403573 & $2.7 \%$ & $2.24[1.02,4.94]$ & & & & \\
\hline Z Li 2018 & 0.1450258 & 0.4929485 & $1.8 \%$ & $1.16[0.44,3.04]$ & & & 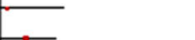 & \\
\hline ZF Xiong 2018 & 0.4618455 & 0.2667893 & $6.1 \%$ & $1.59[0.94,2.68]$ & & & & \\
\hline Subtotal (95\% Cl) & & & $34.2 \%$ & $1.93[1.55,2.41]$ & & & $\boldsymbol{r}$ & \\
\hline $\begin{array}{l}\text { Heterogeneity: } \mathrm{Chi}^{2}=6 \text {. } \\
\text { Test for overall effect: } Z\end{array}$ & $\begin{array}{l}=8(P=0.59) \\
5(P<0.00001\end{array}$ & 1) $1^{2}=0 \%$ & & & & & & \\
\hline Total $(95 \% \mathrm{Cl})$ & & & $100.0 \%$ & $1.82[1.60,2.07]$ & & & $\bullet$ & \\
\hline $\begin{array}{l}\text { Heterogeneity: } \mathrm{Chi}^{2}=2 \mathrm{E} \\
\text { Test for overall effect: } Z \\
\text { Test for subaroun differ }\end{array}$ & $\begin{array}{l}f=24(P=0.3 \\
(P<0.00001 \\
C h i^{2}=0.44\end{array}$ & $\begin{array}{l}34) ; l^{2}=9 \% \\
\text { 1) } \\
d f=1(P=0\end{array}$ & & & 02 & $\begin{array}{l}0.1 \\
\text { Favors [PD-L1+] }\end{array}$ & $\begin{array}{c}10 \\
\text { Favors [PD-L1-] }\end{array}$ & 50 \\
\hline
\end{tabular}

Fig. 4 Meta-analysis of PD-L1 expression on OS (a), DFS (b), and PFS (c) 
Fig. 5 Subgroup analysis of PDL1 expression on OS by using different treatment methods

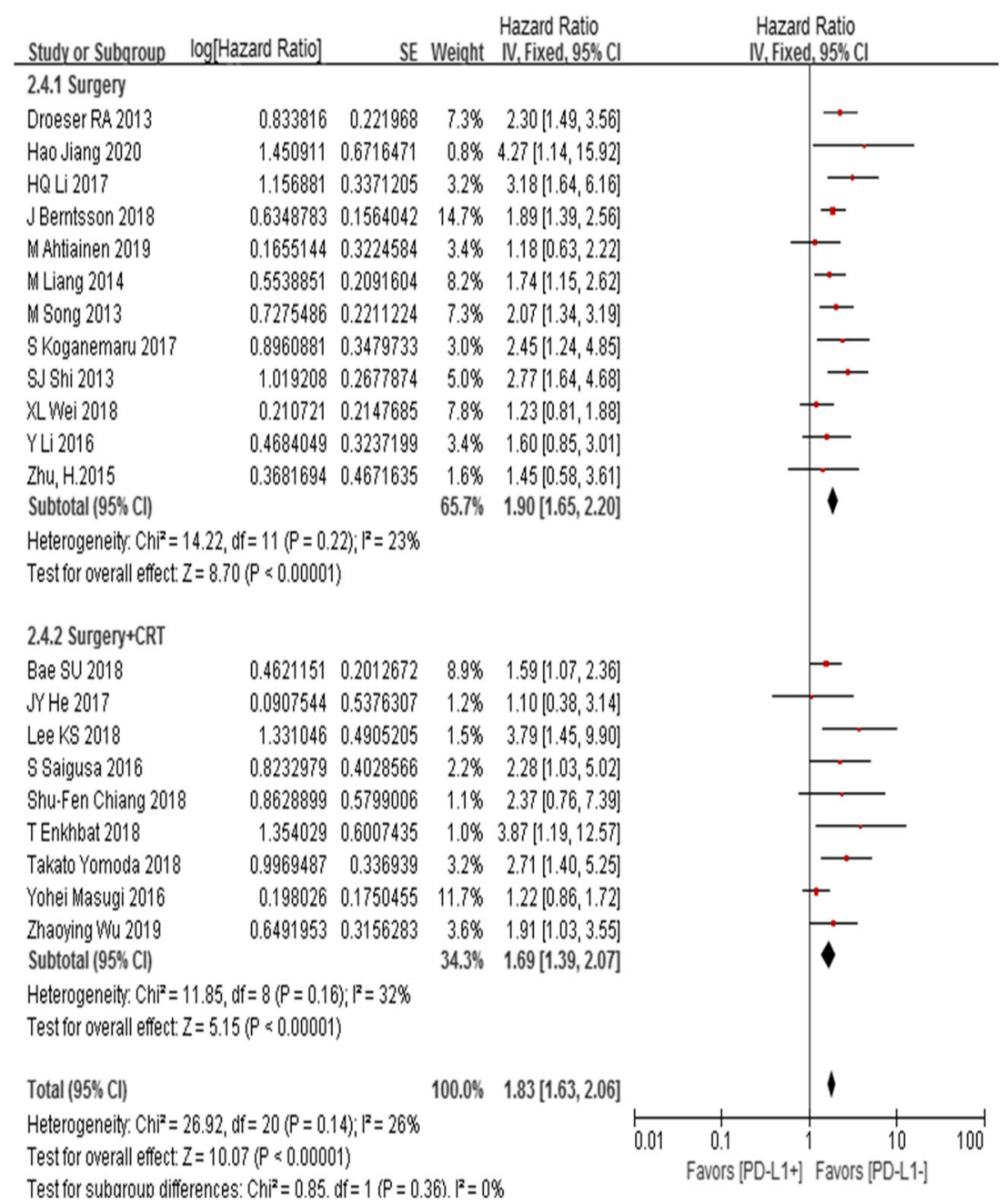

random effect model was chosen. The chi-square test and $I^{2}$ were used to evaluate the heterogeneity of the included studies. Begg's test was used to analyze publication bias by using the software Stata, version 15.1 .

\section{Results}

\section{Description of studies and quality assessment}

Thirty-two eligible studies [25-56] with Newcastle-Ottawa scale (NOS) score $\geq 6$ were included in meta-analysis, including five in Chinese and twenty-seven in English, with a total of 8823 CRC patients. The follow-up duration was from 4 months to 7.3 years, and the sample size was from 65 to 1414. The selection process of literature is detailed in Fig. 1. Basic information and quality evaluation of included studies are presented in Table 1 and Table 2.

\section{Correlation between PD-L1 expression and clinico- pathological features}

The pooled OR indicated that there were significant positive correlations between PD-L1 expression and lymphatic metastasis (yes/no; $n=22 ; 3870$ patients; OR $=1.24,95 \%$ CI $(1.11$, 1.38), $Z=3.72, P<0.05 ; I^{2}=48 \%, P<0.1$ ) (Fig. $2 \mathrm{a}$ ) and tumor diameter $(\geq 5 \mathrm{~cm} /<5 \mathrm{~cm} ; n=10 ; 1536$ patients; $\mathrm{OR}=1.34$, 95\% CI $\left.(1.06,1.70), Z=2.46, P<0.05 ; I^{2}=37 \%, P=0.11\right)$ (Fig. 2b), but negative correlation with differentiation (highmiddle/low; $n=21 ; 5319$ patients; OR $=0.68,95 \%$ CI $(0.53$, 0.87), $Z=3.10, P<0.05 ; I^{2}=47 \%, P<0.1$ ) (Fig. 3a) and vascular invasion (yes/no; $n=14 ; 4201$ patients; OR $=0.80,95 \%$ CI (0.69, 0.92), $Z=3.11, P<0.05 ; I^{2}=29 \%, P=0.14$ ) (Fig. $3 b)$. However, there were no significant correlations found between PD-L1 expression and sex (male/female; $n=29 ; 8043$ patients; OR $=0.94,95 \%$ CI $(0.85,1.04), Z=1.16, P>0.05$; $\left.I^{2}=11 \%, P=0.29\right)$ (Fig. S1A), age $(\geq 60 /<60$ years old; $n=21$; 4095 patients; $\mathrm{OR}=0.96,95 \%$ CI $(0.84,1.10), Z=0.54$, 
Table $3 \mathrm{HR}$ and 95\% CI in meta-regression analysis for CRC prognosis

\begin{tabular}{|c|c|c|c|c|c|c|}
\hline Prognosis & Variables & HR & Standard error & $Z$ & $P$ & $95 \% \mathrm{CI}$ \\
\hline \multirow[t]{3}{*}{ OS } & Distant metastasis (no/yes) & 3.22 & 1.11 & 2.91 & $<0.05$ & {$[1.05,5.39]$} \\
\hline & Treatment methods (surgery/surgery + CRT) & 1.05 & 0.03 & 41.57 & $<0.05$ & {$[1.00,1.10]$} \\
\hline & PD-L1 (negative/positive) & 1.95 & 0.01 & 3.98 & $<0.05$ & {$[1.92,3.98]$} \\
\hline \multirow[t]{2}{*}{ DFS } & Treatment methods (surgery/surgery + CRT) & 0.84 & 0.30 & 2.75 & $<0.05$ & {$[0.24,1.43]$} \\
\hline & PD-L1 (negative/positive) & 2.14 & 0.21 & 3.77 & $<0.05$ & {$[0.73,4.52]$} \\
\hline
\end{tabular}

Sex, age, differentiation, lymphatic metastasis, infiltration degree, distant metastasis, tumor diameter, vascular invasion, TNM stage, tumor type, tumor location, PD-L1 expression, and treatment methods were used as adjustment factors in meta-regression analysis

$\left.P>0.05 ; I^{2}=24 \%, P=0.15\right)($ Fig. S1B), TNM stage (III-IV/III; $n=23 ; 5108$ patients; OR $=1.11,95 \% \mathrm{CI}(0.86,1.43), Z=$ $0.81, P>0.05 ; I^{2}=57 \%, P<0.1$ ) (Fig. S2A), tumor location $($ right + rectal/left + colon; $n=16 ; 4421$ patients; $\mathrm{OR}=1.28$, $95 \%$ CI $\left.(0.95,1.74), Z=1.60, P>0.05 ; I^{2}=65 \%, P<0.1\right)$ (Fig. 3c), infiltration degree (3-4/1-2; $n=10 ; 1837$ patients; $\mathrm{OR}=0.82,95 \% \mathrm{CI}(0.64,1.06), Z=1.52, P>0.05 ; I^{2}=19 \%$, $P=0.27$ ) (Fig. S2B), and distant metastasis (yes/no; $n=10$; 2486 patients; $\mathrm{OR}=1.13,95 \%$ CI $(0.87,1.47), Z=0.91$, $P>0.05 ; I^{2}=30 \%, P=0.18$ ) (Fig. S2C).

\section{Correlation between PD-L1 expression and the prog- nostic parameters (OS, DFS, and PFS)}

Twenty studies provided the OS parameters. As weak heterogeneity existed $\left(I^{2}=39 \%, P=0.03\right)$, the random effects model was used. Meta-analysis showed that OS was significantly associated with PD-L1 expression in CRC patients $(n=21 ; \mathrm{HR}=1.93,95 \%$ CI $(1.66,2.25)$, $Z=8.46, P<0.05)$ (Fig. 4a).

Sixteen studies provided the DFS parameters. Results showed that DFS was significantly associated with PD-L1 expression in CRC patients $(n=16 ; \mathrm{HR}=1.76,95 \% \mathrm{CI}$ (1.50, 2.07), $Z=6.97, P<0.05 ; I^{2}=23 \%, P=0.20$ ) (Fig. 4b).

Nine studies provided the PFS parameters. Results showed that PFS was significantly associated with PD-L1 expression in $\mathrm{CRC}$ patients $(n=9 ; \mathrm{HR}=1.82,95 \% \mathrm{CI}(1.60,2.07), Z=$ 5.85, $P<0.05 ; I^{2}=0 \%, P=0.59$ ) (Fig. 4c).

\section{Subgroup analysis on OS under different treatment methods}

Results were as follows: (1) surgery: PD-L1 expression was significantly associated with $\mathrm{OS}(n=12 ; \mathrm{HR}=1.90,95 \% \mathrm{CI}$ (1.65, 2.20), $\left.Z=8.70, P<0.05 ; I^{2}=23 \%, P=0.22\right)$; (2) surgery + CRT: PD-L1 expression was significantly associated with OS $(n=9 ; \mathrm{HR}=1.69,95 \%$ CI $(1.39,2.07), Z=5.15$, $P<0.05 ; I^{2}=32 \%, P=0.16$ ) (Fig. 5).

\section{Meta-regression analysis}

Meta-regression analysis confirmed that PD-L1 expression was to be correlated with $\mathrm{OS}(\mathrm{HR}=1.95,95 \% \mathrm{CI}(1.92$, $3.98)$ ) and DFS $(\mathrm{HR}=2.14,95 \% \mathrm{CI}(0.73,4.52))$. And the prognosis of patients with surgery treatment alone was worse than that of surgery combined with CRT. Patients with distant metastasis had a poor prognosis (Table 3 ).

\section{Sensitivity analysis}

Sensitivity analysis on OS, DFS, and PFS indicated that after excluding any single study individually, there was no separate study that significantly affected HR and 95\% CI, suggesting that the results of this meta-analysis were stable (Fig. S3).

\section{Publication bias}

Results of Begg's test suggested that there may be no publication bias among studies for OS, DFS, and PFS (all $P>0.05$ ) (Fig. 6).

\section{Discussion}

Studies reported that the PD-1/PD-L1 pathway has become a promising therapeutic target for various human malignancies [17, 18, 57-60]. Nonetheless, the correlation between PD-L1 expression and clinicopathological features [26, 30] and the prognosis of CRC patients are still controversial [36, 51]. Therefore, this study comprehensively searched the literature to solve the above-existing controversies in order to draw more reliable conclusions.

Data of our meta-analysis from 32 studies (8823 CRC patients), the largest to date, indicated that PD-L1 expression was significantly positively correlated with lymphatic metastasis and tumor diameter, but negatively correlated with differentiation and vascular invasion. However previous meta-analysis found that PD-L1 expression was correlated with tumor stage [21] and gender [22] and tumor location [23], which results were 
a Begg's funnel plot with pseudo $95 \%$ confidence limits

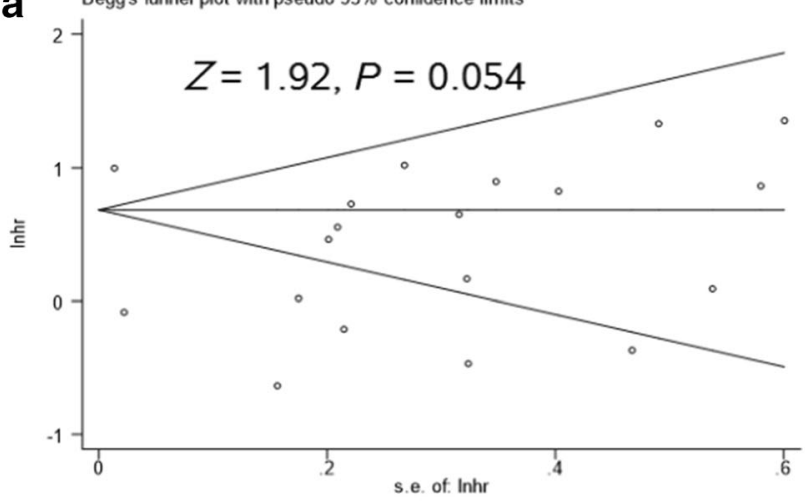

b Begg's funnel plot with pseudo $95 \%$ confidence limits

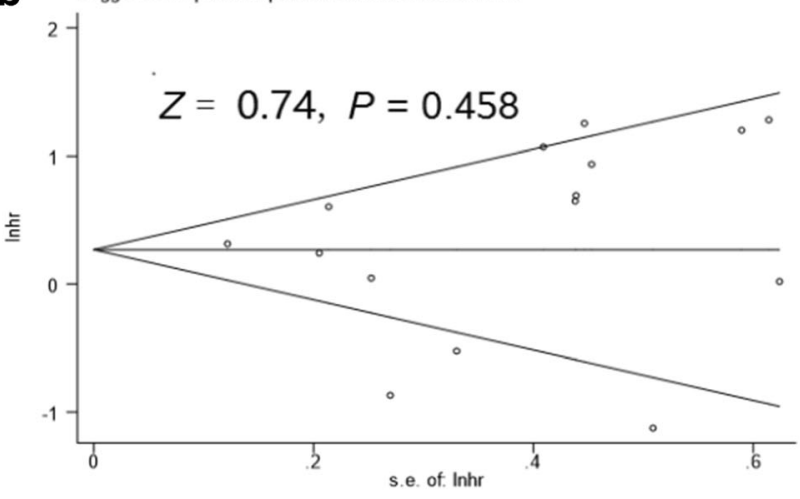

C Begg's funnel plot with pseudo $95 \%$ confidence limits

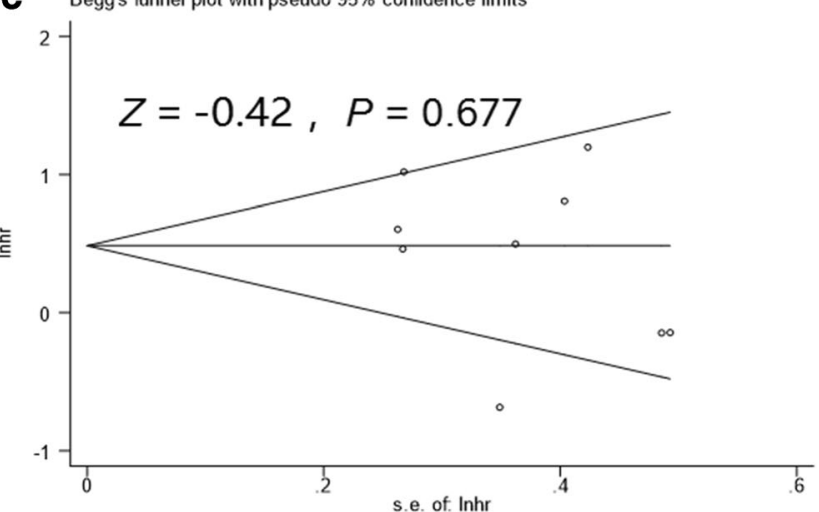

Fig. 6 Begg's funnel plot for OS (a), DFS (b), and PFS (c) publication bias in the included studies

unreliable due to high heterogeneity (all $I^{2}>70 \%$ ) [21-23] and the incorrect analytical model (all selected the fixed effects model that is available for $I^{2}<50 \%$ ) [21-23]. In this study, the random effects model was selected for TNM stage and tumor location because of mild heterogeneity $\left(I^{2}=57 \%\right.$ for TNM stage and $I^{2}=65 \%$ for tumor location).

In univariate analysis, PD-L1 was correlated with poor prognosis of CRC in this study, which was similar to the results of previous meta-analysis [20-23]. However, high heterogeneity existed in our study and those meta-analyses [20-23]. Furthermore, in subgroup analysis based on treatment, we found that the degree of statistical heterogeneity reduced both in subgroup for OS (Fig. 5). It meant that the treatment method was the source of heterogeneity for OS. In order to control other confounders, meta-analysis should be necessary to analyze the independent role of PD-L1 on CRC prognosis. We found that PD-L1 expression independently predicted a poor prognostic outcome with meta-regression analysis. Previous meta-analysis made a contradictory conclusion by univariate analysis [20-23]. Meta-regression analysis can get a more reliable and accurate outcome after adjusting confounders including clinicopathological features and treatment methods that influence the CRC prognosis.

In our sensitivity analysis, none of the inclusions and exclusions of specific studies one by one materially changed the results of the primary meta-analysis; it suggested that the results of this meta-analysis were stable.

From the perspective of publication bias, Begg's test on OS, DFS, and PFS found that there was no significant publication bias that existed among included studies, and the results of this study were relatively reliable.

Despite some positive findings from this meta-analysis, two limitations still existed to our study. Firstly, although Chinese and English studies were included in this meta-analysis, language bias still existed. Secondly, although the literature screening was carried out with a strict search strategy, a small number of literatures including gray literature and conference literature may still be missing.

\section{Conclusions}

In summary, PD-L1 expression was significant correlated with lymphatic metastasis, tumor diameter, differentiation, and vascular invasion, and could act as an independently poor prognostic factor for CRC.

Authors' contributions All authors have read and approved the final manuscript. The corresponding author of this manuscript is Jihong $\mathrm{Hu}$, and contribution of the authors was mentioned below with their responsibility in the research. All authors of this research paper have directly participated in the planning, execution, or analysis and interpretation of data and have read and approved the final version submitted. The contribution of each author is as follows: conceptualization, Jihong Hu; data curation, Shuxia Wang, Xibo Liu, and Mingyang Li; formal analysis, Jing Cao and Bo Yuan; methodology, Changtian Li and Yun Wang; writingoriginal draft, Shuxia Wang; designed the research and revised, Jihong $\mathrm{Hu}$.

Funding The research project was funded and supervised by the National Natural Science Foundation of China (NO.81960614).

Data availability The data supporting this meta-analysis are from previously published studies, which have been cited. The processed data are available from the first author (wangshuxialucky@163.com) upon request. 


\section{Compliance with ethical standards}

Conflict of interest The authors declare that they have no conflict of interest.

Open Access This article is licensed under a Creative Commons Attribution 4.0 International License, which permits use, sharing, adaptation, distribution and reproduction in any medium or format, as long as you give appropriate credit to the original author(s) and the source, provide a link to the Creative Commons licence, and indicate if changes were made. The images or other third party material in this article are included in the article's Creative Commons licence, unless indicated otherwise in a credit line to the material. If material is not included in the article's Creative Commons licence and your intended use is not permitted by statutory regulation or exceeds the permitted use, you will need to obtain permission directly from the copyright holder. To view a copy of this licence, visit http://creativecommons.org/licenses/by/4.0/.

\section{References}

1. Global cancer statistics (2018) GLOBOCAN estimates of incidence and mortality worldwide for 36 cancers in 185 countries. CA Cancer J Clin 2018(68):394-424

2. Siegel RL, Torre LA, Soerjomataram I, Hayes RB, Bray F, Weber TK, Jemal A (2019) Global patterns and trends in colorectal cancer incidence in young adults. BMJ 68:2179-2185

3. National Clinical Research Certer For Digestive Diseases(shanghai), Alliance of National Centers for the Prevention and Treatment of Early Gastrointestinal Carcinoma, Chinese Medical Association Digestive Endoscopy Branch et al (2019) Consensus of the expert consensus on the screening process of the early colorectal cancer in China (2019, Shanghai). Chinese J Int Med 58:736-744

4. Ansa BE, Coughlin SS, Alema-Mensah E, Smith SA (2018) Evaluation of colorectal cancer incidence trends in the United States (2000-2014). J Clin Med 7:22

5. Feng R-M, Zong Y-N, Cao S-M, Xu R-H (2019) Current cancer situation in China: good or bad news from the 2018 global cancer statistics? Cancer Commun (Lond) 39:22

6. Chen W, Zheng R, Baade PD, Zhang SW, Zeng HM, Bray F, Jemal A, Yu XQ, He J (2016) Cancer statistics in China, 2015. CA Cancer J Clin 66:115-132

7. Yang J, Du XL, Li ST, Wang BY, Wu YY, Chen ZL, Lv M, Shen YW, Wang X, Dong DF (2016) Features of differently located colorectal cancers support proximal and distal classification: a population-based study of 57,847 patients. PLoS One 11:e0167540

8. Yamada R, Yamaguchi T, Iijima T, Wakaume R, Takao M, Koizumi K, Hishima T, Horiguchi SI (2018) Differences in histological features and PD-L1 expression between sporadic microsatellite instability and Lynch-syndrome-associated disease in Japanese patients with colorectal cancer. Int J Clin Oncol 23: 504-513

9. Steiner B, Ferrucci LM, Mirabello L, Lan Q, Hu W, Liao LM, Savage SA, De Vivo I, Hayes RB, Rajaraman P (2020) Association between coffee drinking and telomere length in the prostate, lung, colorectal, and ovarian cancer screening trial. PLoS One 15:e226972

10. Ushigome M, Shimada H, Miura Y, Yoshida K, Kaneko T, Koda T, Nagashima Y, Suzuki T, Kagami S, Funahashi K (2019) Changing pattern of tumor markers in recurrent colorectal cancer patients before surgery to recurrence: serum p53 antibodies, CA19-9 and
CEA. Int J Clin Oncol 25:622-632. https://doi.org/10.1007/ s10147-019-01597-6

11. Jeon MH, Jang SW, Lee CM, Kim SB (2019) Early colon cancer recurring as liver metastasis without local recurrence three years after complete endoscopic mucosal resection. Case Rep Gastroenteral 13:403-409

12. Morse MA, Hochster H, Benson A (2020) Perspectives on treatment of metastatic colorectal cancer with immune checkpoint inhibitor therapy. Oncologist 25:33-45

13. Lorenc Z, Waniczek D, Lorenc-Podgórska K, Krawczyk W, Domagała M, Majewski M, Mazurek U (2017) Profile of expression of genes encoding matrix metallopeptidase 9(MMP9), matrix metallopeptidase 28 (MMP28) and TIMP metallopeptidase inhibitor 1(TIMP1) in colorectal cancer: assessment of the role in diagnosis and prognostication. Med Sci Monit 23:1305-1311

14. Fletcher R, Wang YJ, Schoen RE, Finn OJ, Yu J, Zhang L (2018) Colorectal cancer prevention: immune modulation taking the stage. BiochimBiophysActa 1869:138-148

15. Miller KD, Nogueira L, Mariotto AB, Rowland JH, Yabroff KR, Alfano CM, Jemal A, Kramer JL, Siegel RL, Miller KD (2019) Cancer treatment and survivorship statistics, 2019. CA Cancer J Clin 69:363-385

16. Shi Y (2018) Regulatory mechanisms of PD-L1 expression in cancer cells. Cancer Immunol Immunother 67:1481-1489

17. Qin T, Zeng Y-d, Qin G, Xu F, Lu J-b, Fang W-f, Xue C, Zhan J-h, Zhang X-k, Zheng Q-f et al (2015) High PD-L1 expression was associated with poor prognosis in 870 Chinese patients with breast cancer. Onco-target 6:33972-33980

18. Tamura T, Ohira M, Tanaka H, Muguruma K, Toyokawa T, Kubo N, Sakurai K, Amano R, Kimura K, Shibutani M (2015) Programmed death-1 ligand-1 (PDL1) expression is associated with the prognosis of patients with stage II/III gastric cancer. Anticancer Res 35:5369-5376

19. Abiko K, Matsumura N, Hamanishi J (2015) IFN- $\gamma$ from lymphocytes induces PD-L1 expression and promotes progression of ovarian cancer. Br J Cancer 112:1501-1509

20. Shen Z, Gu L, Mao D, Chen M, Jin R (2019) Clinicopathological and prognostic significance of PD-L1 expression in colorectal cancer: a systematic review and meta-analysis. World J Surg Oncol 17:4

21. Yang L, Xue R, Pan C (2019) Prognostic and clinicopathological value of PD-L1 in colorectal cancer: a systematic review and metaanalysis. Onco Targets Ther 12:3671-3682

22. Ni X, Sun X, Wang D, Chen Y, Zhang Y, Li W, Wang L, Suo J (2019) The clinicopathological and prognostic value of programmed death-ligand 1 in colorectal cancer: a meta-analysis. ClinTrans1Oncol 21(5):674-686

23. Li Y, He M, Zhou Y, Yang C, Wei S, Bian X, Odong C, Xie L (2019) The prognostic and clinicopathological roles of PD-L1 expression in colorectal cancer: a systematic review and meta-analysis. Front Pharmacol 10:139

24. Wells GA, SHEA B, Peterson J, Welch V, Losos M, Tugwell P, Wells GA, Connell DO, Shea B (2015) The Newcastle-Ottawa scale (NOS) for assessing the quality of non-randomized studies in meta-analyses. Ottawa Hospital Research Institute, Ottawa, ON

25. Ogura A, Akiyoshi T, Yamamoto N (2018) Pattern of programmed cell death-ligand 1 expression and CD8-positive T-cell infiltration before and after chemoradiotherapy in rectal cancer. Eur J Cancer 91:11-20

26. Bae SU, Jeong WK, Baek SK, Kim NK, Hwang I (2018) Prognostic impact of programmed cell death ligand 1 expression on long-term oncologic outcomes in colorectal cancer. Oncol Lett 16:5214-5222 
27. Berntsson J, Eberhard J, Nodin B, Leandersson K, Larsson AH, Jirström K (2018) Expression of programmed cell death protein 1(PD-1) and its ligand PD-L1 in colorectal cancer: correlation with side-ness and prognosis. Oncoimmunology 7:e1465165

28. Huang CY, Chiang SF, Ke TW, Chen TW, You YS, Chen WT, Chao KSC (2018) Clinical significance of programmed death 1 ligand-1 (CD274/PD-L1) and intra-tumoral CD8+ T-cell infiltration in stage II-III colorectal cancer. Nature 8:1-10

29. Droeser RA, Hirt C, Viehl CT et al (2013) Clinical impact of programmed cell death ligand 1 expression in colorectal carcinoma. Eur J Carcinoma 49:2233-2242

30. Enkhbat T, Nishi M, Takasu C, Yoshikawa K, Jun H, Tokunaga T, Kashihara H, Ishikawa D, Shimada M (2018) Programmed cell death ligand 1 expression is an independent prognostic factor in colorectal cancer. Anticancer Res 38:3367-3373

31. Li HQ, Cao M, Jiang T, Wu ZY, Xu YX, Xu W, Song J (2017) Expression of PD-L1 expression in colorectal cancer and its clinical value. J Xuzhou Med Univ 37:227-230

32. Zhu H, Qin H, Huang Z, Li S, Zhu X, He J, Yang J, Yu X, Yi X (2015) Clinical significance of programmed death ligand-1(PD-L1) in colorectal serrated adenocarcinoma. Int J Clin Exp Pathol 8:9351-9359

33. Jiang $H$, Zhang R, Jiang H, Zhang M, Guo W, Zhang J, Zhou X, Pan W, Zhao S, Li P (2020) Retrospective analysis of the prognostic value of PD-L1 expression and 18F-FDG PET/CT metabolic parameters in colorectal cancer. J Cancer 11:2864-2873

34. Xu J (2016) Analysis of related factors and prognosis of PD-L1 expression in rectal cancer. PLA Medical College. https://kns. cnki.net/KCMS/detail/detail.aspx?dbname=CMFD2017 01\& filename $=1016235857 . \mathrm{nh}$

35. He JY (2017) The impact of radiotherapy on programmed death ligandlexpression in locally advanced rectal cancer and analysis of prognostic factors. Fujian Medical University. https://kns.cnki.net/KCMS/detail/ detail.aspx?dbname $=$ CMFD201802\&filename $=1017858174 . \mathrm{nh}$

36. Koganemaru S, Inoshita N, Miura Y, Miyama Y, Fukui Y, Ozaki Y, Tomizawa K, Hanaoka Y, Toda S, Suyama K, Tanabe Y (2017) Prognostic value of programmed death-ligand 1 expression in patients with stage III colorectal cancer. Cancer Sci 108:853-858

37. Wang L (2019) The expression and clinical pathological significance of PD-L1/Foxp3+ Treg cells in colorectal carcinomas tissues. Lanzhou University. https://kns.cnki.net/KCMS/detail/detail.aspx? dbname $=$ CMFD201902\&filename $=1019875361 . \mathrm{nh}$

38. Lee KS, Kim BH, Oh HK, Kim DW, Kang SB, Kim H, Shin E (2018) Programmed cell death ligand-1 protein expression and CD274/PD-L1 gene amplification in colorectal cancer: implications for prognosis. Cancer Sci 109:2957-2969

39. Lee LH, Cavalcanti MS, Segal NH, Hechtman JF, Weiser MR, Smith JJ, Garcia-Aguilar J, Sadot E, Ntiamoah P, Markowitz AJ, Shike M, Stadler ZK, Vakiani E, Klimstra DS, Shia J (2016) Patterns and prognostic relevance of PD-1 and PD-L1 expression in colorectal carcinoma. Mod Pathol 29:1433-1442

40. Lee SJ, Jun SY, Lee IH, Kang BW, Park SY, Kim HJ, Park JS, Choi GS, Yoon G, Kim JG (2018) CD274, LAG3, and IDO1 expressions in tumor-infiltrating immune cells as prognostic biomarker for patients with MSI-high colon cancer. J Cancer Res Clin Oncol 144:1005-1014

41. Wang L, Ren F, Wang Q, Baldridge LA, Monn MF, Fisher KW, Sheng W, Zhou X, Du X, Cheng L (2016) Significance of programmed death ligand 1 (PD-L1) immunohistochemical expression in colorectal cancer. Mol Diagn Ther 20:175-181

42. Ahtiainen M, Wirta E-V, Kuopio T, Seppälä T, Rantala J, Mecklin JP, Böhm J (2019) Combined prognostic value of CD274 (PD-L1)/
PDCDI (PD-1) expression and immune cell infiltration in colorectal cancer as per mismatch repair status. Mod Pathol 32:866-883

43. Song $\mathrm{M}$, Chen D, Lu B, Wang C, Zhang J, Huang L, Wang X, Timmons CL, Hu J, Liu B, Wu X, Wang L, Wang J, Liu H (2013) PTEN loss increases PD-L1 protein expression and affects the correlation between PD-L1 expression and clinical parameters in colorectal cancer. PLoS One 8:e65821

44. Liang M, Li J, Wang D, Li S, Sun Y, Sun T, Zhang J, Chen X, Li Q, Sun S (2014) T-cell infiltration and expressions of T lymphocyte co-inhibitory B7-H1 and B7-H4 molecules among colorectal cancer patients in Northeast China's Heilongjiang province. Int Soc Oncol BioMark 35:55-60

45. Shi SJ, Wang LJ, Wang GD, Guo ZY, Wei M, Meng YL, Yang AG, Wen WH (2013) B7-H1 expression is associated with poor prognosis in colorectal carcinoma and regulates the proliferation and invasion of HCT116 colorectal cancer cells. PLoS One 8: e76012

46. Saigusa S, Toiyama Y, Tanaka K, Inoue Y, Mori K, Ide S, Imaoka H, Kawamura M, Mohri Y (2016) Implication of programmed cell death ligand 1 expression in tumor recurrence and prognosis in rectal cancer with neoadjuvant chemoradiotherapy. Japan Soc Clin Oncol 26:946-952

47. Chiang SF, Huang CY, Ke TW, Chen TW, Lan YC, You YS, Chen WT, Chao KSC (2019) Upregulation of tumor PD-L1 by neoadjuvant chemoradiotherapy (neoCRT) confers improved survival in patients with lymph node metastasis of locally advanced rectal cancers. Cancer Immunol Immunother 68:283-296

48. Yomoda T, Sudo T, Kawahara A, Shigaki T, Shimomura S, Tajiri K, Nagasu S, Fujita F, Kinugasa T, Akagi Y (2019) The immunoscore is a superior prognostic tool in stages II and III colorectal cancer and is significantly correlated with programmed deathligand 1 (PD-L1) expression on tumor-infiltrating mononuclear cells. Ann Surg Oncol 26:415-424

49. Lei X, Chen S, Shan T, Chen X, Wu T, Yang Y, Li SL (2018) PDL1 expression in colon cancer and its correlation with clinical pathology and prognosis. Modern Oncol 26:2548-2552

50. Gao X, Chen WR, Li YC (2017) Expression and significance of PD-L1 in colonic carcinoma tissue and its correlation with prognosis. J Shantou Univ Med Coll 30:11-14

51. Wei XL, Wu QN, Chen DL, Zeng ZL, Lu JB, Liu ZX, Ju HQ, Ren C, Pan ZZ, Wang FH, Xu RH (2018) The clinical and biomarker association of programmed death ligand 1 and its spatial heterogeneous expression in colorectal cancer. J Cancer 9:4325-4333

52. Masugi Y, Nishihara R, Yang J, Mima K, da Silva A, Shi Y, Inamura K, Cao Y, Song M, Nowak JA, Liao X, Nosho K, Chan AT, Giannakis M, Bass AJ, Hodi FS, Freeman GJ, Rodig S, Fuchs CS, Qian ZR, Ogino S (2017) Tumour CD274 (PD-L1) expression and $\mathrm{T}$ cells in colorectal cancer. Gut 66:1463-1473

53. Li Y, Liang L, Dai WX, Cai GX, Xu Y, Li XX, Li QG, Cai SJ (2016) Prognostic impact of programed cell death-1 (PD-1) and PD-ligand 1 (PD-L1) expression in cancer cells and tumor infiltrating lymphocytes in colorectal cancer. Mol Cancer 15:55

54. Xiong ZF, Xiong QY, Wan HP, Shi J, Ai JH, Xiang D (2018) Clinical expression of programmed death molecular ligand 1 in colorectal cancer pathological significance. Guangdong Med J 39:3652-3656

55. Zhe L (2018) The correlation between PD-L1 expression and clinicopathological features and prognosis of colorectal cancer. Peking Union Medical College. https://kns.cnki.net/KCMS/detail/detail. aspx ?dbname $=$ CDFDLAST2019\&filename $=1019009268 . \mathrm{nh}$ 
56. Wu Z, Yang L, Shi L, Song H, Shi P, Yang T, Fan R, Jiang T, Song J (2019) Prognostic impact of adenosine receptor 2 (A2aR) and programmed cell death ligand 1 (PD-L1) expression in colorectal cancer. Biomed Res Int 2019:8014627

57. Nguyen HD, Liao YC, Ho YS, Chen LC, Chang HW, Cheng TC, Liu D, Lee WR, Shen SC, Wu CH, Tu SH (2019) The $\alpha 9$ nicotinic acetylcholine receptor mediates nicotine-induced PD-L1 expression and regulates melanoma cell proliferation and migration. Cancers 11:1991

58. Aguiar PN Jr, Santoro IL, Tadokoro H, de Lima LG, Filardi BA, Oliveira P, Mountzios G, de Mello RA (2016) The role of PD-L1 expression as a predictive biomarker in advanced non-small-cell lung cancer: a network meta-analysis. Immunotherapy 8:479-488
59. Yu D, Liu X, Han G, Liu Y, Zhao X, Wang D, Bian X, Gu T, Wen L (2019) The let-7 family of microRNAs suppresses immune evasion in head and neck squamous cell carcinoma by promoting PDL1 degradation. Cell Commun Signal 17:173

60. Uccini S, Al-Jadiry MF, Pepe G, Scarpino S, Al-Hadad SA, Ruco L (2019) PD-L1 expression in pediatric Epstein-Barr virus positive classic Hodgkin lymphoma is not associated with 9p24.1 amplification. Pediatr Blood Cancer 66:e27757

Publisher's note Springer Nature remains neutral with regard to jurisdictional claims in published maps and institutional affiliations. 